\title{
Penerapan Strategi Pembelajaran Aktif Tipe Student Recap untuk Meningkatkan Keterampilan Menulis Berita pada Siswa Kelas VIII B SMP Negeri 2 Paloh
}

\author{
Usa $^{1}$, Mardian $^{2}$, Lili Yanti ${ }^{3}$ \\ STKIPSingkawang, Singkawang, Indonesia \\ usadariah95@gmail.com ${ }^{1}$,mardiandeeza@gmail.com², ${ }^{2}$ liliyantiana18@gmail.com³
}

\begin{tabular}{ll}
\hline \hline Keywords : & ABSTRACT \\
Pembelajaran Aktif Student & Penelitian ini dilatarbelakangi oleh rendahnya nilai pada \\
Recap, Keterampilan Menulis & keterampilan menulis siswa dalam pembelajaran bahasa \\
Berita & Indonesia di SMP Negeri 2 Paloh, disebabkan yaitu siswa \\
& masih kurang menguasai kalimat yang akan digunakan dalam \\
& menulis serta siswa belum memahami dalam penulisan tanda \\
& baca. Tujuan secara khusus yang ingin dicapai oleh peneliti \\
yaitu Peningkatan hasil, Keterlaksanaan, Respon siswa & setelah menerapkan strategi pembelajaran student recap \\
untuk keterampilan menulis berita pada siswa kelas VIII B \\
SMP Negeri 2 Paloh. Bentuk penelitian ini pre-eksperimental \\
dengan rancangan one group pretest-postest. Dalam \\
rancangan penelitian ini dilakukan pengukuran berupa pretest \\
kemudian diberikan perlakuan dengan jangka waktu tertentu, \\
kemudian dilakukan pengukuran berupa posttest. Instrumen \\
tes berupa tes essai yang telah diuji cobakan dengan \\
reliabilitas 0,63 kriteria tinggi. Berdasarkan perbandingan tes \\
awal (pretest) sebelum perlakuan dan tes akhir (posttest) \\
setelah diberi perlakuan dengan strategi pembelajaran aktif \\
tipe student recap diperoleh hasil nilai siswa posttest lebih \\
tinggi dari nilai pretest, sehingga dieroleh nilai N-gain \\
sebesar 0,49 dengan kriteria sedang. Keterlaksanaan strategi \\
pembelajaran aktif tipe student recap pada materi menulis \\
berita secara singkat, padat, dan jelas memperoleh nilai \\
sebesar $91,17 \%$. Dengan demikian, dapat disimpulkan bahwa \\
pelaksanaan materi menulis berita secara singkat, padat, dan \\
jelas dengan menulis berita melalui penerapan strategi \\
pembelajaran aktif tipe student recap di kelas VIII B SMP \\
Negeri 2 Paloh dapat dikatakan meningkat. \\
\hline
\end{tabular}

\section{PENDAHULUAN}

Pendidikan merupakan faktor utama dalam pembentukan pribadi manusia. Pendidikan sangat penting dalam kehidupan dan tidak dapat dipisahkan dari kehidupan. Sifatnya mutlak dalam kehidupan, baik dalam kehidupan seseorang, keluarga, maupun bangsa dan negara. Maju-mundurnya suatu bangsa banyak ditemukan oleh maju-mundurnya pendidikan bangsa itu. Mengingat sangat pentingnya bagi kehidupan, maka pendidikan harus dilaksanakan sebaik-baiknya sehingga memperoleh hasil yang 
diharapkan. Pendidikan yang bermutu dapat menunjang pembangunan di segala bidang. Oleh karena itu, pemerintah terus menata dan memperbaiki sistem pendidikan di Indonesia.

Keterampilan berbahasa mencakup empat aspek, yaitu keterampilan menyimak, berbicara, membaca, dan menulis. Setiap keterampilan mempunyai hubungan yang erat satu dengan yang lainnya. Setiap keterampilan itu erat pula berhubungan dengan proses-proses yang mendasari bahasa. Bahasa seseorang mencerminkan pikirannya. Semakin terampil seseorang berbahasa, semakin cerah dan jelas pula jalan pikirannya. Menurut Tarigan (2008: 22) "Menulis ialah menurunkan atau melukiskan lambang-lambang grafik yang menggambarkan suatu bahasa yang dipahami oleh seseorang, sehingga orang-orang lain dapat membaca lambang-lambang grafik tersebut kalau mereka memahami bahasa dan gambaran grafik itu". Dari uraian tersebut dapat disimpulkan bahwa menulis merupakan suatu keterampilan berbahasa yang dipergunakan untuk berkomunikasi secara tidak langsung, tidak secara tatap muka dengan orang lain. Dalam kurikulum tingkat satuan pendidikan (KTSP) terdapat pembelajaran bahasa Indonesia dengan materi menulis berita dengan Standar Kompetensi 12. Mengungkapkan informasi dalam bentuk rangkuman, teks berita, slogan/poster. Kompetensi Dasar 12. 2 Menulis teks berita secara singkat, padat,dan jelas.

Menulis ialah menurunkan atau melukiskan lambang-lambang grafik yang menggambarkan suatu bahasa yang dipahami oleh seseorang, sehingga orang-orang lain dapat membaca lambang-lambang tersebut. Menulis sangat penting bagi pendidikan karena memudahkan para pelajar berpikir secara kritis, dapat memudahkan merasakan dan menikmati hubungan-hubungan, memperdalam daya tanggap atau persepsi, dan memecahkan masalah-masalah yang dihadapi. Petunjuk melakukan sesuatu merupakan panduan bagi seseorang untuk melakukan sesuatu yang diinginkan.

Berdasarkan hasil wawancara dengan guru mata pelajaran bahasa Indonesia di SMP Negeri 2 Paloh khususnya kelas VIII, data hasil belajar siswa pada aspek menulis semester lalu masih belum mencapai Kriteria Ketuntasan Minimal (KKM) yaitu 70. Dari tiga kelas VIII, nilai rata-rata kelas VIII B dari 21 siswa, hanya 10 siswa yang mencapai persentasi ketuntasan yaitu 40\%, sedangkan 11 siswa lainnya belum mencapai nilai KKM yaitu 60\%. Sedangkan untuk kelas VIII A dan VIII C khususnya dalam aspek keterampilan menulis masih di atas nilai rata-rata kelas VIII B. Oleh karena itu peneliti memilih kelas VIII B sebagai objek penelitian adalah dengan melihat hasil belajar siswa yang masih kurang dan setelah melakukan wawancara dengan guru mata pelajaran peneliti dapat menemukan masalah yang dihadapi siswa yaitu siswa masih kurang menguasai kalimat yang akan digunakan dalam menulis serta siswa belum memahami dalam penulisan tanda baca, hal ini dilakukan agar di kelas VIII B dapat memperoleh nilai yang baik dalam materi pembelajaran berikutnya yaitu menulis berita.

Adapun upaya untuk meningkatkan hasil pembelajaran menulis berita siswa, diperlukan suatu strategi pembelajaran yang komunikatif dan aktif sehingga dapat membangkitkan daya perhatian siswa terhadap materi pembelajaran. Strategi pembelajaran merupakan perencanaan yang berisi tentang rangkaian kegiatan yang didesain untuk mencapai tujuan pendidikan tertentu. Strategi pembelajaran yang dipilih oleh peneliti adalah strategi pembelajaran student recap. Menurut Silberman (2002: 253) "Student recap merupakan strategi yang memberikan kesempatan kepada siswa untuk meringkas apa yang telah mereka pelajari dan menyampaikan ringkasannya kepada orang lain. Ini adalah cara yang baik untuk mendorong siswa untuk meringkas apa yang mereka pelajari dengan caranya sendiri”. Alasan peneliti memilih strategi pembelajaran adalah karena dengan melihat masalah yang dihadapi oleh siswa peneliti tertarik memilih strategi pembelajaran, karena strategi pembelajaran merupakan suatu perencanaan berisi rangkaian kegiatan yang dapat digunakan guru untuk proses pembelajaran yang didesain untuk mencapai tujuan yang telah ditentukan.

Berdasarkan masalah tersebut, peneliti ingin melakukan penelitian dengan judul "Penerapan Strategi Pembelajaran Aktif Tipe Student Recap untuk Meningkatkan Keterampilan Menulis Berita pada Siswa kelas VIII B SMP Negeri 2 Paloh Tahun Ajaran 2017/2018”. Alasan peneliti memilih menulis berita 
karena materi ini berhubungan dengan pemahaman siswa dalam menulis sebuah informasi yang ditulis hanya pokok-pokok informasinya, jadi pada materi ini akan menarik minat siswa, sehingga keterampilan menulis dapat ditingkatkan. Pemilihan kelas VIII B karena rendahnya nilai siswa pada materi menulis berita masih belum mencapai Kriteria Ketuntasan Minimum (KKM).

\section{METODE}

Jenis penelitian yang digunakan dalam penelitian ini adalah penelitian kuantitatif. Penelitian ini menggunakan jenis penelitian Pre-Experimental Designs (nondesigns) dapat dikatakan PreExperimental Designs karena desain ini belum merupakan eksperimen sungguh-sungguh. Desain penelitian yang digunakan dalam penelitian ini peneliti menggunakan rancangan one group pretestposttest design. Dengan demikian perlakuan dapat diketahui lebih akurat, karena dapat membandingkan keadaan sebelum diberi perlakuan. Adapun populasi dalam penelitian ini adalah seluruh siswa kelas VIII SMP Negeri 2 Paloh yang berjumlah 70 siswa yang terbagi menjadi 3 gelas. Sampel yang akan di ambil dalam penelitian ini adalah kelas VIII A dengan jumlah siswa sebanyak 25 siswa. Teknik pengumpulan data dapat dilakukan dengan teknik wawancara, teknik kuesioner (angket), dan teknik observasi. Adapun dalam penelitian ini teknik pengumpulan data yang digunakan adalah sebagai berikut. Teknik observasi langsung, teknik pengukuran, dan teknik komunikasi tidak langsung. Intrumen pengumpulan data yang digunakan dalam penelitian ini adalah tenik observasi dalam menggunakan teknik observasi, cara yang paling efektif adalah melengkapinya dengan format atau blangko pengamatan sebagai instrumen. tes yang digunakan untuk mengukur pengetahuan siswa berupa tes tertulis berupa essay (uraian) soal pre-test digunakan sebelum treatment untuk mengetahui hasil belajar siswa dan soal post-test untuk mengetahui hasil belajar siswa setelah treatment dengan strategi student recap. Lembar angket merupakan serangkaian (daftar) pertanyaan tertulis yang ditujukan kepada siswa (dalam penelitian responden) mengenai masalah-masalah tertentu, yang bertujuan untuk mendapatkan tanggapan dari siswa (responden) tersebut.

Teknik analisis data diartikan sebagai upaya mengolah data menjadi informasi, sehingga karakteristik atau sifat-sifat data tersebut dapat dengan mudah dipahami dan bermanfaat untuk menjawab masalahmasalah yang berkaitan dengan kegiatan penelitian. Untuk menjawab masalah pertama tentang peningkatan hasil belajar siswa dengan menggunakan strategi student recap dapat dirumuskan rumus gain. Untuk menjawab masalah kedua tentang keterlaksanaan strategi student recap di kelas VIII B SMP Negeri 2 Paloh, pada materi menulis berita secara singkat, padat, dan jelas maka pengukuran menggunakan skala Guttman kemudian dihitung persentasenya. Untuk menjawab masalah ketiga, tentang respon siswa pada strategi pembelajaran student recap dapat menggunakan rumus persentase respon belajar siswa memiliki kategori/kriteria. Dari pendapat diatas bahwa peneliti ke tempat penelitian untuk mendapatkan data dan melihat kegiatan proses belajar mengajar yaitu di SMP Negeri 2 Paloh.

\section{HASIL PENELITIAN}

Peningkatan Hasil Belajar Siswa dengan Perhitungan Gain

Gain merupakan selisih antara nilai pretest dan posttest. Untuk memperkuat hasil kesimpulan dan untuk mengukur signifikan peningkatan hasil belajar siswa dalam menulis berita secara singkat, jelas, dan padat.

\section{Tabel 1}

Nilai Rata-rata Kelas Eksperimen

\begin{tabular}{lcc}
\hline Kelas & \multicolumn{3}{c}{ Nilai Rata-rata } \\
\hline & Pre-tes & Post-test \\
Eksperimen (VIII B) & $77,94 \%$ & $91,17 \%$ \\
\hline
\end{tabular}

Berdasarkan tabel diatas Nilai rata-rata kelas eksprimen sebagai berikut: kelas eksperimen yang digunakan untuk penelitian ini adalah kelas VIII B. Kegiatan Pre-test di lakukan sebelum kegiatan pengajaran dilakukan. Pada Pre-test ini siswa mendapatkan nilai sebesar 77,94\% secara keseluruhan. Setelah melakukan kegiatan Pre-Test siswa di berikan kegiatan pengajaran, dan setelah melakukan Post-test siswa terdapat pengingkatan nilai sebesar 91,17\%. 
Berdasarkan perhitungan di atas, dapat diperoleh nilai N-Gain sebesar 0,49 dengan kategori sedang. Dengan demikian, dapat disimpulkan bahwa menerapkan strategi pembelajaran aktif tipe student recap dalam menulis berita secara singkat, padat, dan jelas pada siswa kelas VIII B SMP Negeri 2 Paloh dapat meningkatkan hasil belajar siswa.

Keterlaksanaan Strategi Pembelajaran Student Recap

Observasi yang dilakukan dalam penelitian ini adalah mengetahui keterlaksanaan pembelajaran dengan menggunakan strategi pembelajaran student recap pada materi yang ada dalam Rencana Pelaksanaan Pembelajaran (RPP). Observasi dilakukan dengan menggunakan lembar observasi yang telah disusun, di mana semua di indikator yang diobservasi dalam penelitian ini dikembangkan dalam setiap pembelajaran. Adapun ringkasan data hasil dari observasi dapat dihitung sebagai berikut.

Table 2 Keterlaksanaan Pembelajaran

\begin{tabular}{ccc}
\hline $\begin{array}{c}\text { Penerapan Strategi Pembelajaran Aktif Tipe } \\
\text { Student Recap }\end{array}$ & Pertemuan I & Pertemuan II \\
\hline Jumlah & 53 & 62 \\
Nilai Maximum & 68 & 68 \\
Persentase & $77,94 \%$ & $91,17 \%$ \\
Rata-rata & \multicolumn{2}{c}{$84,55 \%$} \\
\hline
\end{tabular}

Berdasarkan table 2 di atas, pada pertemuan 1 nilai Maximum mendapatkan nilai sebsar 68 dengan persentase $77,94 \%$, pertemuan 2 mendapatkan nilai 68 dengan persentase $91,17 \%$ didapatkan rata-rata keterlaksanaan sebesar $84,55 \%$ dengan kriteria sangat layak. Dengan demikian, dapat disimpulkan bahwa keterlaksanaan pembelajaran pada materi menulis berita secara singkat, padat, dan jelas dengan menerapkan strategi pembelajaran student recap pada siswa kelas VIII B SMP Negeri 2 Paloh sangat baik.

Respon Belajar Siswa

Respon diperoleh melalui penyebaran angket setelah kegiatan pembelajaran menulis berita secara singkat, padat, dan jelas dilaksanakan. Setelah angket terkumpul, tahap selanjutnya peneliti melakukan tabulasi hasil data jawaban siswa terhadap tiap item pada angket.

Berdasarkan hasil respon siswa di atas,dapat diproleh hasil perhitungan yang menjawab kategori SS dan S sebesar 106 atau mencapai 50,46\% lebih besar dari kategori yang menjawab R, TS dan STS sebesar 104 atau mencapai persentase 49,41\%. Sehingga, keseluruhan respon siswa pada materi menulis berita secara singkat, padat, dan jelas mencapai persentase $82,14 \%$ dengan kategori sangat baik.

\section{PEMBAHASAN}

Hasil Kemampuan Menulis Berita secara singkat, padat, dan jelas.

Pembelajaran dengan menggunakan strategi pembelajaran student recap berdasarkan hasil pengolahan data yang telah dilakukan, dapat diketahui hasil belajar siswa pada pembelajaran menulis berita secara singkat, padat, dan jelas dengan menerapkan strategi pembelajaran student recap mengalami peningkatan signifikan. Hal ini dapat dilihat dari perhitungan posttest, diperoleh nilai rata 85,31 yang naik sebesar 14,29 dari nilai rata pretest yaitu sebesar 71,02. Sementara peningkatan hasil belajar siswa dalam menulis berita secara singkat, padat, dan jelas dengan menggunakan strategi student recap di SMP Negeri 2 Paloh diperoleh nilai gain sebesar 0,49 dengan kategori sedang. Hasil penelitian ini juga sejalan dengan penelitian yang dilakukan oleh M. Jaidun dalam Efektivitas penerapan strategi pembelajaran student recap dalam meningkatkan hasil belajar matematika peserta didik kelas IX SMP Negeri 3 Pattallassang yang menyatakan bahwa hasil belajar peserta didik menunjukan bahwa penerapan startegi pemebelajaran Student Recap lebih baik dibandingkan dengan tanpa menggunakan strategi pembelajaran Student Recap. 
Hasil Observasi Keterlaksanaan Strategi Pembelajaran Aktif Tipe Student Recap

Berdasarkan hasil pengamatan terhadap keterlaksanaan strategi pembelajaran student recap, diketahui bahwa peneliti telah melaksanakan kegiatan pembelajaran yang menerapkan strategi pembelajaran student recap pada materi menulis berita dengan baik. Dari hasil perhitungan terhadap tiga belas kegiatan yang diamati terbukti bahwa pada pertemuan pertama memperoleh rata-rata frekuensi keterlaksanaan sebesar 53 atau 77,94\%. Sedangkan pada pertemuan kedua memperoleh rata-rata frekuensi keterlaksanaan sebesar 62 atau 91,17\%. Secara keseluruhan keterlaksanaan strategi pembelajaran student recap antara kedua pertemuan memiliki nilai rata-rata frekuensi keterlaksanaan sebesar 62 atau 91,17\% dengan kriteria sangat layak. Hasil penelitian ini juga sejalan dengan penelitian yang dilakukan Oleh Indriati yang berjudul Penggunaan Strategi Ikhtisar Siswa (Student Recap) untuk meningkatkan hasil belajar pendidikan kewarganegaraan pada materi lembaga dan susunan pemerintahan Kabupaten siswa kelas IV SDN 001 Pagaran Tapah, menunjukan berdasarkan hasil observasi aktivitas siswa, dipeoleh total skor aktivitas siswa selama proses pembelajaran 142 poin dari 8 aktivitas yang diamati. Sehingga didapatkan skor maksimum dari 8 aktivitas adalah 200.

Hasil Angket Respon

Berdasarkan hasil angket respon siswa, dapat diketahui bahwa sebagian besar siswa memberikan tanggapan atau respon setuju dan sangat setuju terhadap 10 perny ataan mengenai penerapan strategi pembelajaran student recap. Angket respon siswa berupa angket tertutup, siswa hanya memilih secara menceklist dari salah satu tanggapan yang telah disediakan. Dari data yang diperoleh, didapatkan persentase siswa yang memilih SS (Sangat Setuju) dan S (Setuju) lebih besar dari pada siswa yang memilih kategori R(Ragu), TS (Tidak Setuju) dan STS (Sangat Tidak Setuju). Berdasarkan deskripsi respon siswa yang telah diketahui, maka dapat disimpulkan secara keseluruhan sebagian besar respon siswa terhadap pembelajaran materi menulis berita secara singkat, padat, dan jelas menunjukkan respon setuju.

\section{KESIMPULAN DAN SARAN}

Berdasarkan hasil pengolahan data yang dilakukan peneliti, maka secara umum dapat disimpulkan bahwa terdapat peningkatan pada keterampilan menulis berita melalui penerapan strategi pembelajaran aktif tipe Student Recap pada siswa kelas VIII B SMP Negeri 2 Paloh tahun Ajaran 2017/2018, secara khusus dapat disimpulkan hasil dari penelitian ini sebagai berikut. 1) Peningkatan hasil belajar siswa dalam menulis berita secara singkat, padat, dan jelas dengan menggunakan strategi pembelajaran student recap diperoleh nilai gain sebesar 0,49 dengan kategori sedang. 2) Keterlaksanaan strategi pembelajaran student recap secara umum yang dilaksanakan yang mencapai persentase 84,55\% dengan kriteria layak. 3) Respon siswa pada angket, dapat disimpulkan bahwa siswa lebih apabila dalam kegiatan belajar mengajar guru dapat menggunakan strategi pembelajaran student recap. Hal ini dapat ditunjukkan rata-rata persentase siswa secara keseluruhan sebesar 83,14\% dengan kategori sangat baik.

Berdasarkan kesimpulan diatas, dengan ini peneliti mengajukan beberapa saran sebagai berikut.

Bagi guru, hasil penelitian ini harap akan menciptkan kondisi yang mendorong guru khususnya mata pelajaran bahasa Indonesia untuk mengimplementasikan strategi pembelajaran yang dapat meningkatkan kgiatan pembelajaran yang satu diantaranya adalah strategi pembelajaran aktif tipe Student Recap.

Bagi peneliti, penelitian ini diharapkan dapat menjadi bahan pertimbangan untuk melakukan penelitian lanjutan dengan hasil yang diharapkan serta perlu untuk memperhatikan faktor yang terindentifikasi diantaranya minat dan respon belajar siswa yang masih rendah, mengevaluasi kembali jika tidak terjadi peningkatan ataupun penilaian pembelajaran yang mendapatkan nilai tetap, pelaksanaan pembelajaran yang kurang efektif, dan siswa tidak fokus menerima materi dan cenderung pasif didalam kelas. 


\section{DAFTAR PUSTAKA}

Artati, budi. 2015. Bahasa Indonesia Kelas VIII Semester 2. Klaten: PT Intan Pariwara.

Dalman. 2015. Keterampilan Menulis. Jakarta: Rajawali Pers.

Jaidun, M. 2016. Efektivitas Penerapan Strategi Pembelajaran Student Recap Dalam Meningkatkan Hasil Belajar Matematika Peserta Didik Pada Kelas IX SMP Negeri 3 Pattallassang.

Nawawi, Hadari. 2012. Metode Penelitian Bidang Sosial. Yogyakarta: Gadjah Mada University Presis.

Noris, Lisman. 2015. Pengaruh Penerapan Strategi Belajar Aktif Tipe Student Recap Terhadap Hasil Belajar Biologi Siswa Kelas XI SMAN 2 Sutera Kabupaten Pesisir Selatan. Di akses pada 20 Maret 2017.

Nurgiyantoro, Burhan.2014. Penilaiaan Pembelajaran Bahasa. Yogyakarta: BPFE-Yogyakarta.

Saddhono \& Slamet. 2012. Meningkatkan Keterampilan Berbahasa Indonesia (Teori dan Aplikasi). Bandung: Karya Putra Darwati.

Semi, Atar. 2007. Dasar-Dasar Keterampilan Menulis. Bandung: Angkasa.

Silberman, Melvin L. 2002. Active Learning 101 Strategi Pembelajaran Aktif. Yogyakarta: Pustaka Insan Madani.

Sugiyono. 2015. Metode Penelitian Pendidikan Pendekatan Kuantitatif, Kualitatif, dan R\&D. Bandung: Alfabeta.

Tarigan, Henry Guntur. 2008. Menulis Sebagai Suatu Keterampilan Berbahasa. Bandung: Angkasa Bandung.

Yunus Mohamad Suparno. 2010. Keterampilan dasar menulis. Jakarta: Universitas terbuka. 